\title{
DINAMIKA UMKM DI GRESIK - JAWA TIMUR PADA PERKEMBANGAN ERA DIGITAL DENGAN PENDEKATAN SISTEM DINAMIK
}

\author{
Putri Amelia $^{1)}$, Brina Miftahurrohmah ${ }^{2)}$ \\ 1), 2) Sistem Informasi, Universitas Internasional Semen Indonesia \\ Kompleks PT. Semen Indonesia (Persero) Tbk. Jl. Veteran, Gresik Jawa Timur, 61122 \\ Email : putri.amelia@uisi.ac.id ${ }^{1)}$,brina.miftahurrohmah@uisi.ac.id ${ }^{2)}$
}

\begin{abstract}
Abstrak
Perkembangan UMKM ini juga harus bisa mengimbangi globalisasi pasar yang menuntut peningkatan daya saing dan strategi bisnis yang saat ini tengah beralih ke era digital. Dari survey yang dilakukan BPS (2016) 67\% UMKM mengalami kendala. Kendala yang sering dihadapi salah satunya adalah pemasaran (31\%). Berdasarkan hasil yang ada, tidak semua UMKM yang ada melakukan implementasi digital didalam membantu kegiatan marketing. Oleh karena itu penelitian kali ini akan dibahas dinamika perubahan permintaan khususnya UMKM makanan perkembangan era digital dengan menggunakan metode pendekatan sistem dinamik. Melalui penggambaran model simuasi akan digambarkan faktor eksternal pelanggan dan faktor internal penjual. Penggambaran model akan dapat diketahui perubahan permintaan sebelum dilakukan implementasi marketing didalam proses bisnis dan saat dilakukan implementasi.
\end{abstract}

Kata kunci: UMKM, Era Digital, Sistem Dinamik, Marketing

\section{Pendahuluan}

Salah satu indikator keberhasilan pembangunan khususnya pada negara berkembang seperti Indonesia dapat dilihat dari keberhasilan pembangunan ekonominya. Pembangunan sendiri ditujukan untuk meningkatkan kesejahteraan masyarakat. Usaha Mikro Kecil dan Menengah (UMKM) membawa peranan penting dalam pertumbuhan dan perkembangan ekonomi di Indonesia. UMKM merupakan bagian integral dari dunia usaha nasional yang mempunyai kedudukan, potensi dan peranan yang sangat strategis dalam mewujudkan tujuan pembangunan nasional(Rahayu and Day, 2017).

UMKM memiliki peran besar dalam perekonomian, khususnya di Kabupaten Gresik, dalam hal menjadi sumber nafkah dan penyerapan tenaga kerja. Dengan pertumbuhan ekonomi sebesar $6,15 \%$ pada tahun 2015 , Kabupaten Gresik mencatat pertumbuhan ekonomi di atas rata-rata Propinsi Jawa Timur sebesar 5,44\% maupun nasional sebesar 4,79\%.(Badan Pusat Statistik, 2016). Kondisi ini berbanding lurus dengan jumlah UMKM yang terus bertumbuh hingga pada 2015 tercatat sebanyak 188.534 unit UMKM(Diskoperindag, 2017)

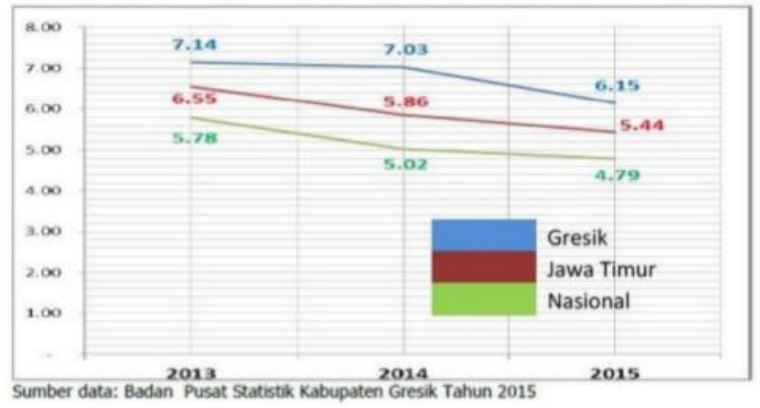

Gambar 1. Pertumbuhan Ekonomi Kabupaten Gresik relative terhadap Propinsi Jawa Timur dan rata-rata nasional

Perkembangan UMKM ini juga harus bisa mengimbangi globalisasi pasar yang menuntut peningkatan daya saing dan strategi bisnis yang saat ini tengah beralih ke era digital. Dari survey yang dilakukan BPS (Badan Pusat Statistik, 2015)67\% UMKM mengalami kendala. Kendala yang sering dihadapi salah satunya adalah pemasaran (31\%). UMKM masih melakukan pemasaran hasil usaha dengan presentase $91 \%$ ke pasar lokal (satu kabupaten/ kota) dan $0,03 \%$ dari bisnis usaha memasarkan hasil usahanya keluar negeri. Selain itu, di era digitalisasi konsumen mampu menggunakan smartphone ataupun laptop mereka untuk melihat, mempertimbangkan atau membeli suatu produk. Dengan perkembangan internet pada saat ini UMKM dapat memasarkan produk-produk mereka tanpa terbatas jarak dan waktu. Oleh karena itu, perkembangan jumlah UMKM selalu berubah-ubah sesuai dengan keadaan perekonomi daerah, akses pemasaran dan faktor-faktor lain yang mempengaruhinya.

Tabel 1. Pertumbuhan UMKM di Kabupaten Gresik 2011-2015

\begin{tabular}{|l|l|l|l|l|l|}
\hline USAHA & $\mathbf{2 0 1 1}$ & $\mathbf{2 0 1 2}$ & $\mathbf{2 0 1 3}$ & $\mathbf{2 0 1 4}$ & $\mathbf{2 0 1 5}$ \\
\hline Mikro & 162.319 & 163.959 & 165.616 & 167.273 & 168.946 \\
\hline Kecil & 17.344 & 17.570 & 17.748 & 17.926 & 18.106 \\
\hline Menengah & 1.422 & 1.477 & 1.452 & 1.467 & 1.482 \\
\hline TOTAL & $\mathbf{1 8 1 . 0 8 5}$ & $\mathbf{1 8 3 . 0 0 6}$ & $\mathbf{1 8 4 . 8 1 6}$ & $\mathbf{1 8 6 . 6 6 6}$ & $\mathbf{1 8 8 . 5 3 4}$ \\
\hline
\end{tabular}

Menurut survey 253 UKM pada usaha Jasa, Manufaktur dan Retail di Kabupaten Gresik yang dilakukan Tikno (Tikno and Amelia, 2019)diketahui bahwa 15\% UMKM memiliki website, 74\% UMKM belum dan ingin punya web site, dan sisanya belum dan tidak ingin punya. 
Sedangkan, berdasarkan berita media social (Detik Online, 2017) dari jumlah UMKM mencapai 60 juta unit termasuk di Gresik. Sayangnya, hanya $8 \%$ saja atau sekitar 3,79 juta pelaku usaha yang sudah memanfaatkan platform online. Berdasarkan hasil yang ada, tidak semua UMKM yang ada melakukan implementasi digital didalam membantu kegiatan marketing.

Oleh karena itu penelitian kali ini akan dibahas dinamika perubahan permintaan khususnya UMKM makanan dan minuman dengan mempertimbangkan perkembangan era digital dengan menggunakan metode pendekatan sistem dinamik. Melalui penggambaran model simuasi akan digambarkan faktor eksternal pelanggan dan faktor internal penjual. Penggambaran model akan dapat diketahui perubahan permintaan sebelum dilakukan implementasi marketing didalam proses bisnis dan saat dilakukan implementasi. Hasil dari penggambaran model akan dapat memberikan usulan perbaikan pada peningkatan jumlah pelanggan.

\section{Pembahasan}

Didalam penggambaran model perlu dibuat model konseptual. Penggambaran model konseptual digambarkan dalam bentuk causal loop (Borshchev and Filippov, 2004). Penggambaran model causal loop akan memberikan hubungan atar variabel yang ada didalamnya. Gambar 1 adalah penggambaran mengenai model konseptual. Berdasarkan causal loop model didapatkan 2 loop tertutup negative dan yang 3 loop positive sebagai berikut:

\section{Loop 1 (positive)}

Loop ini terdiri dari variable pendapatan $\rightarrow$ profit

$\rightarrow$ IT $\rightarrow$ kualitas layanan $\rightarrow$ dinamika layanan

2. Loop 2 (positive)

Loop ini terdiri dari varibel profit $\rightarrow$ marketing $\rightarrow$ pelanggan potensial $\rightarrow$ permintaan $\rightarrow$ pendapatan.

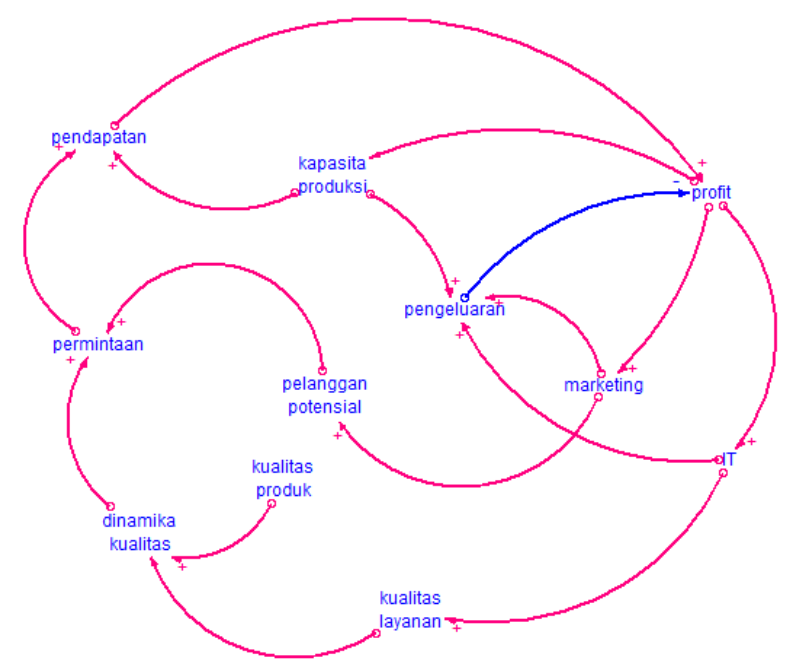

Gambar 2. Causal Loop

3. Loop 3 (positive)

Loop ini terdiri dari variable profit $\rightarrow$ kapasitas produksi $\rightarrow$ pendapatan
4. Loop 4 (negative)

Profit $\rightarrow$ IT $\rightarrow$ Pengeluaran

5. Loop 5 (negative)

Loop ini terdiri dari varibel profit $\rightarrow$ kapasitas produksi $\rightarrow$ pengeluaran

Langkah berikutnya yaitu pembuatan model stock and flow. Pembuatan stock and flow diagram dibuat didasarkan atas causal loop diagram yang sudah ditunjukan pada Gambar 1. Gambar 2 adalah penggambaran model secara keseluruhan. Penggambaran model yang dibuat Didalam model digambarkan bahwa besarnya kapasitas produksi mempengaruhi produk yang dibuat. Bila jumlah kapasitas lebih besar dibandingkan dengan jumlah permintaan, maka besarnya produk yang dibuat akan mengikuti jumlah permintaan. Dan sebaliknya, bila jumlah permintaan lebih besar dibandingkan jumlah kapasitas maka besarnya produk yang dijual mengikuti jumlah kapasitas(Domegan et al., 2016). Selain itu pula didalam model juga digambarkan mengenai dinamika pelanggan. Besarnya jumlah pelanggan dipengaruhi oleh adanya pelanggan baru dan adanya pengurangan pelanggan akibat pengaruh dari luar(Ylén, 2014). Besarnya jumlah pelanggan baru pada penjualan offline akan ditentukan oleh media marketing word of mounth yang dilakukan oleh pekanggan yang sudah ada atau terdahulu(Bianchi and Bivona, 2002). Selain itu pada penggambaran model juga digambarkan mengenai dinamika profit. Pesarnya profit akan dipengaruhi besarnya julah permintaan dan pengeluaran pada UMKM.

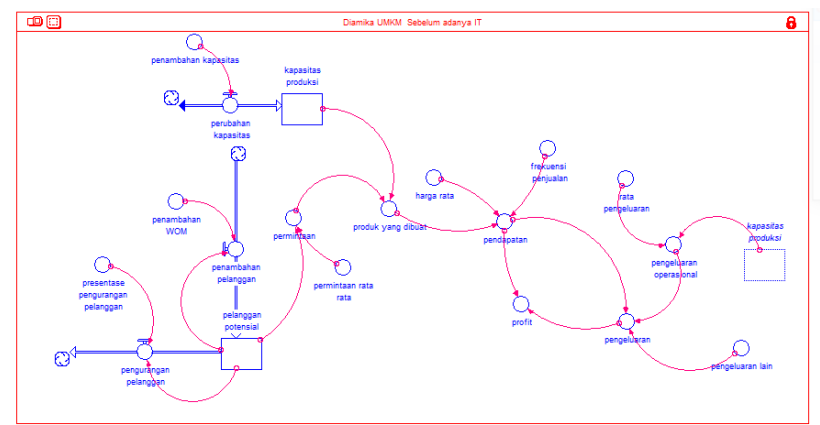

Gambar 3. Stock and Flow Dinamika UMKM Sebelum adanya IT

Validasi model merupakan pengujian terhadap model untuk melihat apakah model sudah mampu mewakili atau menggambarkan sistem nyata. Proses validasi dalam model ini dilakukan menggunakan dua metode, yaitu metode white box dan black box. Metode white box dilakukan dengan memasukan semua variabel serta keterkaitan antar variabel di dalam model yang didapatkan dari orang yang ahli (expert) dalam kasus ini. Sedangkan validasi dengan metode black box dilakukan dengan membandingkan rata-rata nilai data aktual dengan rata-rata nilai data hasil simulasi.

a. Uji Struktur Model

Uji struktur model perlu untuk dilakukan didalam melakukan permodelan sistem dinamik. Hal ini dikarenakan tujuan dari uji struktur model adalah 
melihat apakah struktur model sudah sesuai dengan sistem nyata. Setiap faktor penting dalam sistem nyata harus tercermin dalam model. Pembuatan model melakukan brainstorming dan proses diskusi dengan pemilik UMKM makanan dan minuman dikarenakan pemilik mengetahui pola dan karakteristik yang terkait dengan peningkatan jumlah pelanggan. Metode ini digunakan karena metode ini merupakan metode kualitatif yang paling tepat untuk dapat merepresentasikan validity model.

\section{b. Uji Parameter Model (Model Parameter Test)}

Didalam melakukan uji parameter model dilakukan sebuah uji dengan melihat dua variabel yang saling berhubungan, dan setelah itu membandingkan hasil logika aktual dengan hasil simulasi. Pada model ini, digunakan variabel. Hasil simulasi dikatakan baik jika polanya sama dengan logika aktual. Variabel dalam model yang akan diuji misalnya jumlah pelanggan dan pendapatan. Logika awalnya yaitu bila jumlah pelanggan meningkat maka akan meningkatkan jumlah permintaan. Hal ini akan berdampak pada besarnya jumlah pendapatan yang didapatkan. Berdasarkan hasil Gambar 4, bahwa parameter simulasi model sudah berjalan sesuai dengan logika actual.

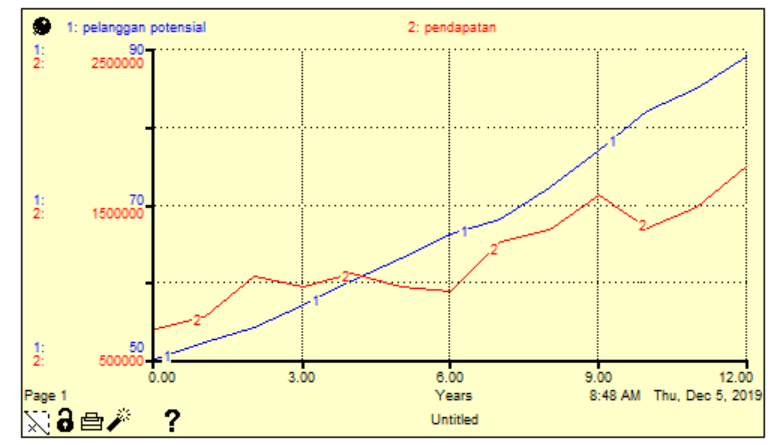

Gambar 4. Uji Parameter

\section{c. Uji Kecukupan Batasan (Boundary Adequancy Test)}

Uji Kecukupan batasan model digunakan untuk melihat batasan model yang dirancang dengan batasan model yang dibuat. Tujuan pembuatan model adalah untuk melihat seberapa besar pengaruh peningkatan investasi pada subsektor industri makanan dan minuman terhadap penyerapan tenaga kerja Langkah pembatasan model sudah dilakukan saat model dibuat yaitu dengan menguji variabel-variabel yang dimasukan dalam model yaitu, jika suatu variabel ternyata tidak berpengaruh secara signifikan terhadap tujuan model, maka variabel tersebut tidak perlu dimasukan dalam model sistem.

\section{d. Uji Kondisi Ekstrim (Extreme Conditions Test)}

Setelah dilakukan uji kecukupan batasan, maka langkah berikutnya yaitu melakukan uji kondisi ekstrim. Uji ini bertujuan untuk menguji kemampuan model pada kondisi ekstrim nilai variabel yang berubah signifikan sehingga memberikan kontribusi sebagai alat evaluasi kebijakan. Pengujian dapat dilakukan dengan memasukan nilai ekstrim terkecil/terbesar lalu dibandingkan dengan standart nilai yang ada. Pada pengujian digunakan variabel pengeluaran. Pada gamnbar awal diketahui bahwa nilai pendapatan dan penjualan akan mempengaruhi profit. Gambar yang kedua yaitu gambar dengan merubah nilai variabel pengeluaran menjadi nilai 0. Bedasarkan hasil yang didapatkan diketahui bahwa besarnya nilai profit akan sama atau sesuai dengan nilai pendapatan.

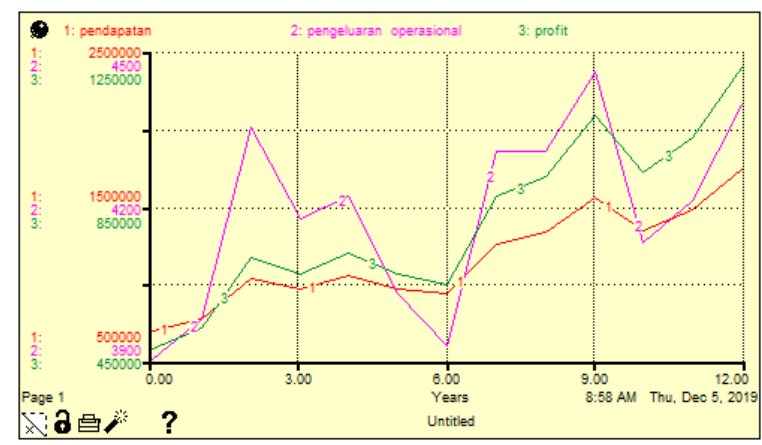

(a) Kondisi awal permodelan

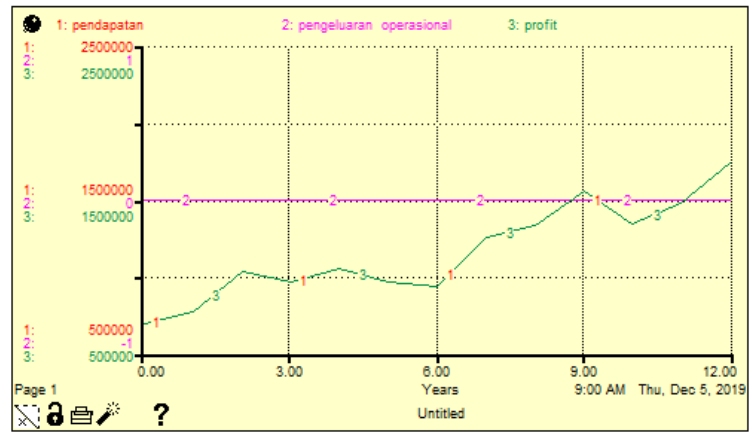

(b) Kondisi saat uji ekstrim

Gambar 5. Uji Kondisi Ekstrim

Berdasarkan hasil simulasi software sebelum dilakukan implementasi IT didalam mendukung kegiatan marketing diketahui pada gambar. Berdasarkan gambar diketahui bahwa besarnya pelanggan disetiap tahun meningkat tetapi peningkatannnya tidak terlalu signifikan. Besarnya peningkatkan jumlah pelanggan akan berdampak pada jumlah permintaan dan juga pada pendapatan, permintaan. Sehingga hal ini akan berdampak pada besarnya profit yang didapatkan disetiap tahunnya.

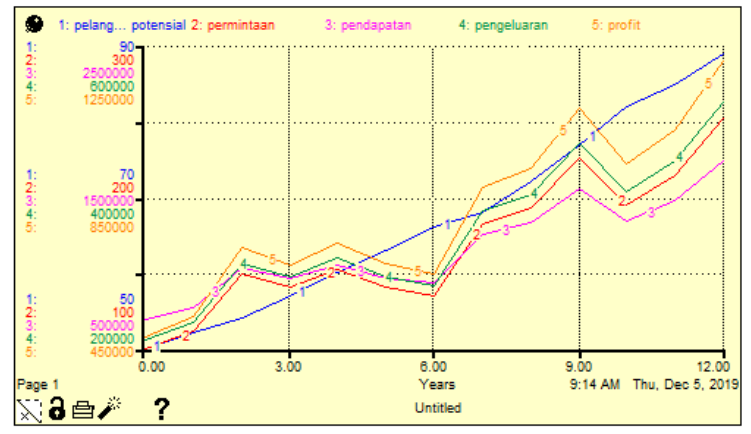

Gambar 6. Hasil Simulasi Model sebelum diimplementasikan IT 
Pada model skenario, implementasi IT didalam media marketing. Dalam hal ini para UMKM selalu meragukan antara biaya yang dikeluarkan untuk kegiatan IT dengan manfaat yang diperolehnya. Dengan melakukan scenario ini akan dapat diperoleh gambaran mengenai dinamika UMKM yang ada. Pada simulasi ini model akan dijalankan selama 12 tahun dengan 5 tahun awal adalah data history, sedangkan tahun 6 hingga ke 12 adalah penggambaran model selama 7 tahun kedepan. Sehingga akan diperoleh dampak akibat pengaruh IT selama 7 tahun kedepan.

Penggambaran model digambarkan pada gambar dibawah ini. Didalam melakukan implementasi IT akan mempengaruhi biaya IT dan biaya pengeluaran. Berdasarkan model kerangka Delone Mclean (Delone and McLean, 2003)bahwa kualitas layanan IT dipengaruhi oleh terhadap kualitas system, kualitas layanan IT, dan kualitas informasi IT. Oleh karena itu, biaya yang dikeluarkan IT akan mempengaruhi 3 variabel tersebut. Infromasi terkait dengan biaya yang mampu dikeluarkan UMKM untuk mengembangkan bisnisnya didapatkan dengan hasil wawancara pemilik UMKM yaitu dengan maksimum $30 \%$ dari nilai profit yang diterima. Sehingga nilai input yang berpengaruh pada akiat dari biaya IT akan berpengaruh sekitar 2\% pada kualitas system, dan $3 \%$ pada nilai kualitas layanan IT dan kualitas informasi IT.

Hasil perubahan implementasi IT pada bisnis usaha ternyata tidak menurunkan nilai profit yang ada. Hal ini terbukti pada gambar garfik antara pengeluaran dan profit yang didapatkan. Meskipun terjadi penambahan pada nilai pengeluaran yang berupa biaya IT, tetapi hal ini tidak menurunkan nilai profit yang didapatkan. Analisa pada model yang dibuat, membuktikan bahwa peningkatan biaya IT akan berdampak pada penambahan jumlah pelanggan di media online atau social media(Bianchi and Bivona, 2002). Sehingga, akan diperoleh permintaan produk yang terus meningkat disetiap tahunnya. Dan membuat pendapatan bisnis juga terus meningkat.

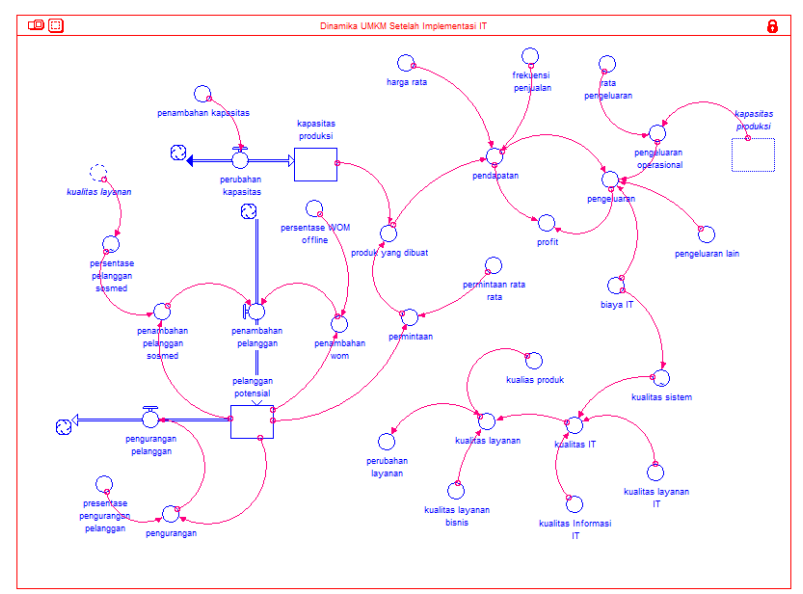

Gambar 7. Stock and Flow Dinamika UMKM Setelah implementasi IT

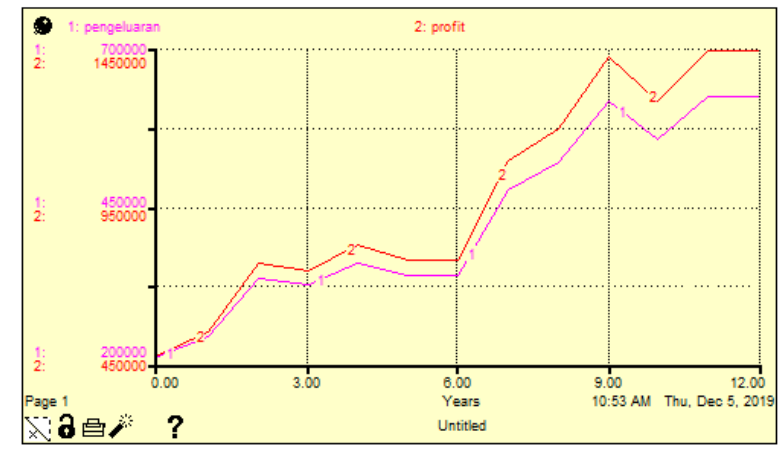

Gambar 8. Hasil Model Setelah implementasi IT

\section{Kesimpulan}

Dari hasil simulasi dan analisis, maka dapat diambil kesimpulan bahwa variabel yang berpengaruh pada jumlah pelanggan yaitu word of mouth (offline), dan pengaruh media social (online). Didalam model dinamika UMKM khususnya pada makanan dan minuman diketahui bahwa dengan melakukan implementasi IT didalam kegiatan marketing akan dapat meningkatkan $20 \%$ jumlah pelanggan, dan $10 \%$ nilai rata-rata pendapatan. Analisa hasil software didapatkan bahwa biaya untuk implementasi IT tidak berpengaruh besar kepada penurunan julah profit yang didapatkan oleh bisnis usaha

\section{Daftar Pustaka}

Badan Pusat Statistik (2015) Profil Industri Mikro dan Kecil Jawa Timur 2015. Surabaya: Badan Pusat Statistik Provinsi Jawa Timur.

Badan Pusat Statistik (2016) No Title, Badan PusatStatistik. Available at: https://www.bps.go.id/ .

Bianchi, C. and Bivona, E. (2002) 'Opportunities and pitfalls related to e-commerce strategies in smallmedium firms: A system dynamics approach', System Dynamics Review, 18(3), pp. 403-429. doi: 10.1002/sdr.256.

Borshchev, A. and Filippov, A. (2004) 'From system dynamics and discrete event to practical agent based modeling: reasons, techniques, tools', in Proceedings of the 22nd international conference of the system dynamics society. Citeseer.

Delone, W. H. and McLean, E. R. (2003) 'The DeLone and McLean Model of Information Systems Success: A Ten-Year Update', Journal of Management Information Systems. Routledge, 19(4), pp. 9-30. doi: 10.1080/07421222.2003.11045748.

Detik Online (2017) Detik Online. Available at: https://finance.detik.com/moneter/3374246/50-jutapelaku-umkm-didorong-untuk-bisa-godigital . 
Diskoperindag (2017) No Title, Dinas Koperasi Usaha Mikro dan Perindag Kabupaten Gresik. Available at: http://gresikkab.go.id/profil/dinas_koperasi_usaha_mikr o_dan_perindag .

Domegan, C. et al. (2016) 'Systems-thinking social marketing: conceptual extensions and empirical investigations', Journal of Marketing Management, 32(11-12), pp. 1123-1144. doi: 10.1080/0267257X.2016.1183697.

Rahayu, R. and Day, J. (2017) 'E-commerce adoption by SMEs in developing countries: evidence from Indonesia', Eurasian Business Review. Springer International Publishing, 7(1), pp. 25-41. doi: 10.1007/s40821-016-0044-6.

Tikno and Amelia, P. (2019) 'Measuring the moderating effect of age, gender and educational level on UMKM go digital program', in AIP Conference Proceedings. doi: 10.1063/1.5098273.

Ylén, J.-P. (2014) 'System dynamic model for ecommerce customer retention strategy', (March). 